http://www.moderntechno.de/index.php/meit/article/view/meit10-03-009

DOI: 10.30890/2567-5273.2019-10-03-009

RETROSPECTIVE ANALYSIS OF VR TECHNOLOGIES AND THEIR IMPLEMENTATION IN EDUCATION

РЕТРОСПЕКТИВНЫЙ АНАЛИЗ ТЕХНОЛОГИЙ ВИРТУАЛЬНОЙ РЕАЛЬНОСТИ И ИХ ПРИМЕНЕНИЕ В СФЕРЕ ОБРАЗОВАНИЯ

Golub T.P. / Голуб Т.П.

PhD, Ass.Prof.

ORCID: 0000-0002-7757-880X

National Technical University of Ukraine "Igor Sikorsky Kyiv Polytechnic Institute",

Kyiv, Ukraine

Abstract. The article is devoted to the study of virtual reality technologies and devices development, as well as to the overview of modern applications used in the educational sphere. The retrospective and historical analysis of the ideas connected to virtual reality covers the period from the Middle Ages to modern times. The main characteristics and peculiarities of VR devices of different times are studied. The possibilities and features of the application of virtual and augmented reality technologies for the organization and implementation in the educational process in secondary schools and higher educational institutions are analyzed.

Key words: virtual reality, education, history.

\title{
Introduction
}

For a long time, virtual reality (VR) seemed to be a sci-fi concept. Then, after the technology ceased to look just a fantasy, scientists, inventors and futurologists began to realize that the combination of equipment can displace a person to completely new worlds while leaving the physical body in real.

Virtual reality is actively used in various areas. It received the most widespread distribution in the entertainment sector: virtual slot machines, 5D / 8D cinemas, etc., video games also use VR elements, including PlayStation VR, PlayStation Eye, Microsoft Kinect, Oculus Rift headsets, and HTC Vive. In addition to entertainment, virtual reality is used in business, medicine, industry, arts, social sphere, scientific studies, etc.

Also, virtual reality devices are often used in the field of education to make the information more visual and to teach new skills. For educational goals virtual reality is promising in terms of the application of the technology as innovative teaching aids. Today it is mainly simulators that allow students to study some system and/or to work with it virtually, for example, to plunge to the bottom of the ocean, to fly into space, to study the internal structure of a human or various physical and chemical phenomena. Such training tools allow students to obtain knowledge and skills regardless of place and time.

\section{The history of VR}

The idea of immersing a person into a non-physical environment arose back in the Middle Ages in the field of art. At that times concave frescoes were created to engage a person in what is happening in the image.

The first stereoscope was invented by Charles Winston in 1837. The principle of the device was as follows: a person looks at two flat images from different points and at different angles, as a result of which the brain creates a three-dimensional image. That is, we can say that Winston created the first prototype of a primitive VR-helmet 
a la Cardboard almost 200 years ago.

Modern virtual reality technology began with an attempt to combine visual perception with the perception of movement and sound. Its initial use predates the invention of the computer. It was a flight simulator "Link Trainer", in the original model of which a moving picture and pneumatic transmissions like organ pipes were used. "Link Trainer", patented in 1929, simulated moves, rotation, fall, changes of course and thus created a satisfactory sense of movement.

In 1957, the filmmaker Norton Heilig developed a unique device "Sensorama", thanks to which he is called the "father of virtual reality". Outwardly, it resembled a kind of slot machine with a seat and a tiny screen. Heilig shot 6 short films into which the user was supposed to "plunge". At first glance, the device looked like some kind of medical equipment, but in fact, it was one of the first attempts to fence off from the real world and get into another universe. "Sensorama" had a 3D display, a small generator, and even a footprint that vibrated when needed. So, "Sensorama" transmitted not only video but also stereo sound, vibrations and smells - for that time it was a truly innovative attraction. However, it did not receive much popularity and further development - technical imperfection and the very format of immersion in VR left much to be desired.

An interesting fact is that in the same 1957, Heilig developed and patented a drawing of a "telescopic mask", which can rightfully be considered the ancestor of modern VR headsets. However, the matter did not go beyond the drawing.

Headsight. The device, which soon received widespread use, began its life as a top-secret military project. In 1961 Philco engineers combined the video screen with a basic tracking system in one helmet and connected everything for CCTV. The main goal of "Headsight" was to remotely observe situations that are too dangerous to be close to them.

GAF Viewmaster. Nothing serious - just another "early version" of Cardboard that allows us to enjoy three-dimensional images. The device was released in 1966 and was the first to give everyone the now familiar feeling of immersion in another world.

The next important milestone in the development of virtual reality technology was created by Harvard University professor Ivan Sutherland and student Bob Sproul in 1968. The system was a primitive VR helmet, which was suspended from the ceiling due to its enormous weight. The design loomed menacingly over a person for which it got its name. "Sword of Damocles" was connected to a computer and transferred the image to the screen. The graphics, of course, were primitive - simple geometric shapes. But the "Sword of Damocles", like "Headsight", could track the

Aspen Map. In 1978, another very important step was taken for the development of virtual reality technology. The videotaped streets of the small town of Aspen, located in Colorado, were transferred to VR and recorded on optical media. By choosing the time of year (winter or summer), the user could take a VR tour of Aspen.

Eye tap. Steve Mann, who is considered to be the father of all wearable smart gadgets, created the first augmented reality helmet prototype in 1980. It was a computer backpack, worn on the back, and a video helmet - the device already very 
much resembled what we have today. Mann harnessed the beam splitter to show the scene to both the user and the computer connected to the camera, which allowed for overlay data in real time. Although Mann's reality was augmented rather than virtual, his subsequent "Eye Tap" prototypes showed that virtual technology does not have to be bulky or unnatural.

$R B 2$. This name was given to the device created in 1984. It allowed us to immerse ourselves in virtual reality together and interact with the artificial world move, rotate objects, in general, do almost anything you want with what happened on the display of the EyePhone VR headset, using the first multifunctional controllers in the form of gloves. Due to the high cost "RB2" has not received the popularity. The entire kit cost $\$ 100,000$, although there was a budget option for $\$ 50,000$.

Virtual environment display system. In 1985 a VR helmet was created, which by its characteristics is the closest to modern devices. The headset was developed by NASA and the device was intended for scientific, and not for entertainment purposes. With its help it was possible, for example, to walk along the surface of the Moon or Mars.

Virtuality. An interesting gaming system that allows us to immerse ourselves in VR, was created in the early 1990s by Virtuality Group. A joystick, a microphone, 2 LCDs in each helmet and the ability to play over the network were very cool. But the low resolution of the display $-276 \times 372$ minimized the effect of immersion.

Project "CAVE". The first working prototype was developed by students of the University of Illinois in 1992. It was a room in which the inner walls served as reflective screens - various stereo images were projected on them. To see a threedimensional picture, it was necessary to wear stereo glasses. Tracking the position of the user's hands and head, as well as a special controller for interacting with the VR world, were also present here. The advantages of CAVE systems are higher image quality, wide viewing angle, low latency when tracking, the ability to see your body and, as a result, the absence of a possible loss of coordination and motion sickness.

Sega VR. The next significant project, a VR helmet from Sega, was presented in 1993. Stylish design, tracking the position of the head, stereo sound - all these advantages did not cause enthusiasm among gamers - seasickness, headaches and other shortcomings that arise during the game "buried" the project.

Cybermaxx. The next attempt to popularize virtual reality is the CyberMaxx helmet released by Victormaxx in 1994. Two-color displays with a resolution of $505 \times 230$ were a good result for that time. But the high cost and system requirements for the PC did not allow the project to develop further.

Oculus Rift. Fundraising on the Kickstarter crowdfunding venue on August 1, 2012, for a project called "Oculus Rift" was the starting point for the further development of VR technology and the industry as a whole. The consumer version of the Oculus Rift CV1 helmet came out only in 4 years and had a resolution of $1080 \times 1200$ pixels for each eye and a 110 degrees viewing. Compared to the VR headsets of the last century, this was a huge breakthrough.

Google Cardboard, Samsung Gear VR and Daydream VR. In 2014, two engineers at Google Corporation David Coz and Damien Henry created the most affordable model of a device for immersion in VR from cardboard and several lenses. 
Of course, such a "cardboard" is not self-sufficient and requires a modern smartphone to work. Daydream VR is another headset from Google, which can conditionally be called an improved Cardboard (Daydream is much cooler and ergonomic). In the same 2014, Samsung Gear VR was introduced, which works on the same principle (requires a smartphone), but has better features and a higher price.

Windows Mixed Reality. The mixed reality platform (virtual and augmented) was introduced by the largest OS developer along with the Microsoft Hololens headset on January 21,2015 . The platform was the first attempt to unite disparate developers into a single whole to standardize, simplify and give impetus to the further development of VR / AR technologies.

\section{$V R$ in education}

Labster. A serious interactive 3D-project developed in partnership with leading universities - Massachusetts Institute of Technology, Harvard and Stanford. Students can remotely conduct experiments in scientific laboratories with a full range of equipment [1]. Labster's 3D Labs service was launched not so long ago, but thousands of students at Stanford, the universities of Hong Kong and Copenhagen are already using it. Least of all is the project reminiscent of a textbook - rather, it is a scientific game, with the help of which you can get comfortable in various fields. And this is not about theory, but about the practice itself - the intricacies of chemical, physical and engineering procedures. The service demonstrates all the processes at the molecular level - chemical and biological experiments take place right in front of the eyes, and not behind the walls of the devices. For those who are not even impressed with this, Labster can simulate a murder and offer to collect evidence. The possibilities are practically unlimited: already today Labster has ready-made laboratories for 15 subjects, such as zoology, botany, virology, general medicine, bioengineering, chemistry, microbiology, etc. By the way, you can also request a new laboratory, describing your expectations in a special form (however, the development process is quite time-consuming, so it will have to wait for its appearance). Besides, the authors are ready to translate the game into other languages.

Expeditions App. The program allows students to go there, "where school buses cannot reach." The virtual platform is conceived as an educational program for school classes, in which a group of employees conducts virtual tours of exotic and amazing places on our planet (the platform has more than 100 such excursions) [2].

Colosseum VR. The creators of this application offer everyone to travel to Ancient Rome to see the Colosseum with their own eyes and visit the center of gladiatorial battles. Also, you can visit the Palatine Hill or the Temple of Venus, explore the arch of Constantine or the Colossus of Nero. Of course, the graphics are still far from ideal, but such an immersion in history will certainly leave no child indifferent.

Mezo VR. With the Mezo VR application, you can not only see the real ongoing archaeological excavations but also follow the schedule of the stages in the history of Maya civilization. Like the previous one, this application is hand-drawn, but the graphics are good enough to interest the ornaments on the walls of ancient buildings.

Titans of space. Another hot topic is space. What is the use of considering the planets of the solar system on the pages of encyclopedias, if they remain luminous 
points in the sky? It is quite another matter to go on a tour where each of the cosmic bodies is reduced a million times. How about twisting a 12.7-meter diameter globe around its axis and viewing it from all sides? Or read detailed information about each of the planets? The creators claim that you haven't touched space so close.

The Apollo 11 VR Experience. The creators of this application claim that they do not want children to learn about important moments in history by simply reading a textbook. That is why they took NASA's archived audio and video materials and tried to recreate the events of 1969, namely, the time of the landing of Neil Armstrong on the moon. So everyone can feel in the place of the famous astronaut.

zSpace. These guys offered their version of the application of technology in education. They developed glasses for schoolchildren, functioning according to the example of 3D: everyone who is wearing glasses at that moment sees the image. Using an interactive pen, children can control the molecular lattice model or look at the human body step by step. The system was tested at Lee High School and caused great enthusiasm.

There are many other VR applications in education, for instance, to study of nature - "Alchemy Learning" [3] and VIRRY VR [4], astronomy - "Titans of Space" and "Mars Is A Real Place" [5] and much more. For AR, this is "My Lab" to study chemistry [6], and "Sky Map" to study astronomy [7].

VR and AR technologies are often mentioned in immersive education programs [8 - 11]. Such programs include the use of modern information technologies in the learning process, which takes place inside various virtual worlds and simulations, often in a playful way. This type of training helps to increase involvement, communication between students and interest in the subject.

\section{Conclusion}

With great certainty, we can say that we are on the verge of a new technological revolution that will erase the boundaries between the real and the many fictional worlds. Work, fun, study, business and more will soon be gone to VR to stay there forever.

\section{References:}

1. A million-dollar lab, one click away. - URL: https://www.labster.com/.

2. Bring your lessons to life with Expeditions. - URL: https://edu.google.com/products/vr-ar/expeditions/?modal_active=none\#header.

3 . Babcock $\mathrm{S}$. This edtech startup is bringing virtual reality to the classroom. Alchemy Learning is using Oculus Rift to bring lessons to life. - URL: https:/technical.ly/baltimore/2015/05/29/alchemy-learning-virtual-reality-classroomoculus/.

4. VIRRY VR. Instant getaway to Kenyan wildlife. - URL: http://www.virryvr.com/.

5. Virtual Engineering by DrashVR LLC. - URL: http://www.titansofspacevr.com/.

6. My Lab. - URL: https://www.microsoft.com/enus/p/mylab/9nn8dz3j8ksx?activetab=pivot:overviewtab.

7. Sky Map. - URL: 
https://play.google.com/store/apps/details?id=com.google.android.stardroid\&hl=en.

8. Immersive Education Initiative. Blckchain an Education. - URL: http://immersiveeducation.org/.

9. VR. Immersive Education. Learn through Experience. - URL: https://immersivevreducation.com/.

10. Rizzotto L. The Future of Education: How A.I. and Immersive Tech Will Reshape Learning Forever. - URL: https://medium.com/futurepi/a-vision-foreducation-and-its-immersive-a-i-driven-future-b5a9d34ce26d.

11. Improving Biotech Education Through Gamified Laboratory Simulations. Mads T. Bonde et al, Nature Biotechnology Vol. 32, 2014.

Анотація. Стаття присвячена вивченню технологій та пристроїв віртуальної реальності, а також огляду застосування сучасних технологій віртуальної реальності в освітній сфері. Ретроспективний та історичний аналіз ідей, пов'язаних з віртуальною реальністю, охоплює період від середньовіччя до сучасності. Досліджено основні характеристики та особливості VR-пристроїв різних часів. Проаналізовано можливості та особливості застосування технологій віртуальної та доповненої реальності в навчальний прочес середніх та вищих навчальних закладів.

Ключові слова: віртуальна реальність, освіта, історія.

Article sent: 15.12.2019

(C) Golub T.P. 